Jurnal Keperawatan Silampari

Volume 5, Nomor 1, Desember 2021

e-ISSN: 2581-1975

p-ISSN: 2597-7482

DOI: https://doi.org/10.31539/jks.v5i1.2915

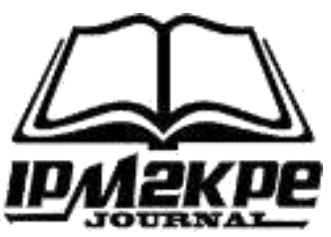

\title{
BUDAYA SIRI'NA PACCE TERHADAP SELF ESTEEM PEREMPUAN DENGAN HIV/AIDS DI KOTA MAKASSAR MELALUI PENDEKATAN TRANSCULTURAL NURSING
}

\author{
Brigita Sri Jane $^{1}$, Mutiara Cyesa Prasasti Ngandoh ${ }^{2}$, \\ Dea Nur Shabrina Hidayat ${ }^{3}$, Framita Rahman ${ }^{4}$, Arnis Puspitha $\mathrm{R}^{5}$ \\ Universitas Hasanuddin ${ }^{1,2,3,4,5}$ \\ arnispuspitha2018@gmail.com ${ }^{5}$
}

\begin{abstract}
ABSTRAK
Penelitian ini bertujuan untuk mengetahui pengaruh budaya siri' na pacce terhadap self esteem perempuan dengan HIV/AIDS serta faktor-faktor yang mempengaruhi tingkat self esteem perempuan dengan HIV/AIDS di kota Makassar. Metode penelitian ini adalah penelitian mix method dengan menggunakan pendekatan transcultural nursing Hasil Penelitian ditemukan bahwa seluruh responden masih menganut budaya siri' na pacce dalam keluarga mereka. Berdasarkan hasil analisis data kuesioner, sebagian besar responden memiliki tingkat self esteem sedang dalam keluarga mereka. Simpulan, faktor yang mempengaruhi hal tersebut adalah budaya siri'na pacce yang masih dipegang teguh oleh masyarakat Bugis Makassar, tingkat pendidikan serta adanya dukungan moral yang didapatkan dari keluarga sehingga perempuan ODHA dapat menjalani kehidupan sehari-hari secara normal meskipun hanya membuka status HIV kepada keluarga terdekat.
\end{abstract}

Kata Kunci: HIV/AIDS, Self Esteem, Siri’na Pacce, Transcultural Nursing

\section{ABSTRACT}

This study aims to determine the influence of siri'na pacce culture on women's selfesteem with HIV/AIDS and the factors that influence the level of self-esteem of women with HIV/AIDS in the city of Makassar. This research method is mixed-method research using a transcultural nursing approach. The study results found that all respondents still adhere to the siri'na pacce culture in their families. Based on the questionnaire data analysis, most of the respondents had moderate levels of self-esteem in their families. In conclusion, the factors that influence this are the siri'na pacce culture which is still adhered to by the Bugis Makassar community, the level of education, and the moral support obtained from the family so that women living with HIV can live everyday daily lives even though they only reveal their HIV status to their families. Closest.

Keywords: HIV/AIDS, Self Esteem, Siri'na Pacce, Transcultural Nursing 


\section{PENDAHULUAN}

World Health Organization melaporkan bahwa HIV terus menjadi masalah utama kesehatan masyarakat global, setelah merenggut hampir 33 juta nyawa selama ini (WHO, 2020). Di Indonesia sendiri, HIV/AIDS masih menjadi permasalahan kesehatan yang belum dapat diselesaikan hingga saat ini. Bahkan terjadi peningkatan angka penemuan kasus HIV/AIDS setiap tahunnya. Meskipun cenderung fluktuatif, data kasus HIV/AIDS di Indonesia terus meningkat dari tahun ke tahun. Selama sebelas tahun terakhir jumlah kasus HIV di Indonesia mencapai puncaknya pada tahun 2019, yaitu sebanyak 50.282 kasus, dimana Sulawesi Selatan berada pada posisi kesembilan provinsi dengan jumlah kasus HIV terbanyak pada tahun 2019 yaitu sebanyak 1.537 kasus (Khairunisa et al., 2020).

Perempuan menjadi salah satu populasi yang rentan terkena HIV/AIDS. Hal ini terjadi tidak hanya pada kelompok berisiko seperti mereka yang sering berganti-ganti pasangan, pekerja seksual, serta pemakai narkoba khususnya narkoba suntik, tetapi juga menginfeksi perempuan ataupun istri dan ibu rumah tangga yang setia pada pasangannya. Menurut laporan Direktorat Jenderal Pencegahan dan Pengendaliaan Penyakit (P2P) tahun 2020, persentase perempuan yang terinfeksi HIV/AIDS adalah $33 \%$ dengan jumlah kasus AIDS pada ibu rumah tangga sebanyak 18.463 sedangkan kasus pada penjaja seks sebanyak 3.613 kasus. Selain itu, kerentanan pada perempuan juga ditambah dari bentuk organ kelamin yang seperti bejana terbuka. Secara fisik, ini memudahkan virus masuk ke dalam vagina ketika berhubungan seksual dengan lelaki yang positif HIV, melalui luka kecil atau lecet atau masuknya cairan sperma ke dalam vagina (Moreno-de-Lara et al., 2021).

Perempuan dengan HIV/AIDS memiliki beban psikososial yang lebih berat dibandingkan dengan pria. Beban psikososial yang mereka hadapi cukup kompleks, terdiri dari perubahan self esteem, perawatan anggota keluarga terhadap individu yang terinfeksi HIV/AIDS, kematian anggota keluarga, dan beban pekerjaan untuk mendukung keluarga secara finansial jika suami mereka meninggal, kehilangan hak asuh mereka, menginfeksi anak-anak mereka dan rasa bersalah yang mendalam. Perempuan yang terkena HIV/AIDS, secara psikologis akan mengalami berbagai masalah, mulai dari kecemasan, keraguan, stress dan depresi. Tekanan lingkungan yang cenderung diskriminatif akan membuat perempuan kehilangan penghargaan terhadap dirinya (Timisela, 2018).

Masyarakat seringkali memberikan anggapan negatif bagi pasien ODHA, sehingga stigma negatif tersebut akan mempengaruhi ODHA dalam merespon terhadap adaptasi fisiologisnya (Andri et al., 2020). Penelitian yang dilakukan Maharani (2018) hasil penelitian menunjukkan bahwa masyarakat memberikan cap negatif terhadap ODHA sehingga cap negatif tersebut menyebabkan diskriminasi dalam masyarakat seperti pengucilan, penolakan, penghindaran.

Salah satu hal yang mempengaruhi penerimaan masyarakat terhadap perempuan dengan HIV/AIDS adalah adanya budaya yang berkembang di masyarakat tersebut. Salah satu contohnya adalah budaya siri'na pacce yang masih dipegang teguh oleh masyarakat suku Bugis Makassar. Siri' adalah suatu sistem nilai sosial, budaya dan kepribadian yang merupakan pranata pertahanan harga diri dan martabat manusia sebagai individu dan anggota masyarakat. Kata siri' dalam bahasa Makassar berarti malu atau rasa malu, maksudnya siri'lanri anggaukanna anu kodi, artinya malu apabila melakukan perbuatan tercela. Namun selain itu budaya siri'na pacce juga memiliki makna lain yang terkandung dalam kata pacce. Pacce dalam bahasa Makassar dan pesse 
dalam bahasa Bugis merupakan rasa kemanusiaan yang adil dan beradab, semangat rela berkorban, bekerja keras, dan pantang mundur. Pada dasarnya siri' dan pacce merupakan suatu falsafah yang tidak dapat dipisahkan, karena antara satu dengan yang lainnya mempunyai keterkaitan makna dan hubungan, sehingga dalam hal pembagian siri' dan pacce, keduanya saling berkaitan erat (Fuady, 2019).

Berdasarkan penelitian terdahulu yang dilakukan oleh Safitri \& Suharno (2020) disimpulkan bahwa siri'na pacce dalam interaksi sosial suku di Makassar merupakan sebagai harga diri dan solidaritas kemanusiaan. Melalui budaya siri', mereka berusaha menjunjung tinggi harkat dan martabat mereka sebagai individu di dalam masyarakat. Budaya siri' juga berfungsi sebagai upaya pengekangan bagi seseorang untuk melakukan tindakan persekusi yang dilarang oleh kaidah adat sehingga dapat menguatkan motivasi solidaritas sosial dalam penegakan harkat siri' orang lain (Hijriani \& Herman, 2019). Bagi orang Bugis tidak ada tujuan atau alasan hidup yang lebih tinggi atau lebih penting daripada menjaga siri' dan kalau mereka merasa tersinggung atau ripakasiri (dipermalukan) maka mereka lebih senang memilih mati dengan perkelahian guna memulihkan siri' mereka daripada hidup tanpa siri'. Dengan adanya budaya ini mereka berusaha mempertahankan harga diri mereka dengan menghindari perbuatan-perbuatan tercela yang dianggap melanggar aturan (Zainal \& Wahyuni, 2018).

Budaya siri,na pacce yang sampai saat ini masih dipegang teguh oleh masyarakat suku Bugis Makassar tentunya sangat mempengaruhi cara pandang dan penerimaan mereka terhadap ODHA khususnya perempuan. Mereka dianggap telah melanggar budaya siri' tersebut karena adanya stigma dan diskriminasi yang berkembang di masyarakat. Masyarakat masih menganggap bahwa HIV/AIDS adalah penyakit pada mereka yang kurang moral karena tertular melalui hubungan seks, dan para pecandu narkoba. Tak hanya dari masyarakat sekitar, stigma maupun diskriminasi ini juga dapat timbul dari lingkungan keluarga ODHA sendiri. Menurut Yani et al., (2020) apabila terdapat ODHA dalam keluarga, mereka merasa takut untuk tidur bersama dengan ODHA dan tidak bersedia merawat seperti menyiapkan makanan dan membersihkan peralatan makan, serta duduk dekat dengan orang-orang terinfeksi HIV yang tidak menunjukkan gejala sakit. Akibatnya mereka menutupi status HIV keluarganya karena mereka merasa ripakasiri (dipermalukan) apabila masyarakat tahu bahwa anggota keluarga mereka terinfeksi HIV/AIDS.

Adanya stigma dan diskriminasi yang diterima oleh ODHA khususnya pada perempuan, dapat mempengaruhi tingkat self esteem mereka. Mereka akan cenderung memandang diri mereka tidak berharga karena adanya asumsi sosial yang menjatuhkan harga diri mereka atau dapat dikatakan mereka telah dipermalukan (siri'ri pakasirik). Self esteem merupakan salah satu bagian dari kepribadian seseorang yang sangat penting dalam kehidupan sehari-hari. Self esteem adalah evaluasi yang dibuat oleh individu dan biasanya berhubungan dengan penghargaan terhadap dirinya sendiri, hal ini mengekspresikan suatu sikap setuju atau tidak setuju dan menunjukan tingkat dimana individu itu meyakini diri sendiri mampu, penting, berhasil dan berharga (Shimizu et al., 2021). Seseorang dengan harga rendah cenderung merasa tidak dicintai dan sering mengalami depresi dan kecemasan. Setiap manusia perlu memiliki self esteem yang tinggi terutama mereka para perempuan yang siri' mereka terancam karena diri mereka yang terjangkit HIV/AIDS. Adanya self esteem yang tinggi akan menjadikan seseorang pribadi yang efektif dan produktif serta dapat melakukan relasi sosial yang lebih positif. Oleh karena itu, setiap individu perlu memandang dirinya 
maupun mendapatkan penghargaan dari orang lain sebagai pribadi yang berharga, sehingga mereka mampu menguasai tugas dan mampu menghadapi tantangan dalam kehidupannya (Pardede et al., 2021).

Dalam keperawatan pengkajian budaya terhadap kesehatan dapat dilakukan berdasarkan teori transcultural nursing. Menurut Leininger 2002 dalam McFarland \& Wehbe-Alamah (2019) transcultural nursing adalah suatu area/wilayah keilmuan budaya pada belajar dan praktik keperawatan yang fokus memandang perbedaan dan kesamaan antara budaya dengan menghargai asuhan, sehat dan sakit didasarkan pada nilai budaya kepercayaan dan tindakan, dan ilmu ini digunakan untuk memberikan asuhan keperawatan khususnya budaya atau keutuhan budaya kepada manusia. Pengkajian transcultural nursing dilakukan dengan menggunakan sunrise model yang terdiri dari 7 (tujuh) faktor untuk mengidentifikasi masalah kesehatan berdasarkan latar belakang budaya (Soares et al., 2020).

Penelitian ini berfokus untuk mengetahui, dan menganalisis bagaimana gambaran self esteem perempuan dengan HIV/AIDS di Kota Makassar dan mengidentifikasi faktor-faktor budaya apa saja yang mungkin berpengaruh pada self esteem perempuan ODHIV dan hal ini belum pernah diteliti sebelumnya. Penelitian ini juga menggunakan metode transcultural nursing dalam memahami fenomena terkait HIV/AIDS yang dimana metode ini terbilang masih sangat jarang digunakan.

\section{METODE PENELITIAN}

Pendekatan transcultural nursing digunakan dalam penelitian ini. Transcultural nursing adalah sebuah metode penelitian kualitatif menggunakan pendekatan naturalistik, penemuan yang bersifat terbuka dengan mengkombinasikan bermacam strategi, teknik dan dokumen-dokumen pendukung untuk menggambarkan, menginterpretasikan, mengekspresikan simbol dan berbagai budaya yang berhubungan dengan fenomena dunia kesehatan. Dalam penelitian ini menggunakan 2 metode transcultural nursing yang dimodifikasi yaitu; wawancara kepada informan kunci dan informan general serta observation-participation-reflection.

Populasi pada penelitian ini adalah semua perempuan yang hidup dengan HIV/AIDS di Kota Makassar yang bersuku Bugis Makassar. Adapun metode pengambilan sampel menggunakan metode nonprobability sample, accidental sample . Kriteria inklusi pada penelitian ini yaitu; perempuan yang telah terinfeksi HIV/AIDS selama $\geq 6$ bulan dan mengetahui status positif HIV setidaknya selama 3 bulan terakhir serta bersedia memberikan informasi yang berkaitan dengan penelitian, bersuku Bugis/Makassar, dan memiliki pengetahuan dasar tentang konsep siri'na pacce.

Pengumpulan data dengan pendekatan transcultural nursing melibatkan 3 tahap yaitu pengisian kuesioner, focus group discussion, dan wawancara mendalam (in depth interview) yang melibatkan 6 orang informan kunci yang merupakan perempuan ODHA dan 5 orang informan general yang merupakan keluarga/kerabat dari ODHA tersebut. Proses pertama adalah pengisian kuesioner rosenberg self esteem scale untuk mengukur tingkat self esteem yang dilakukan secara daring melalui google form kepada informan kunci. Proses kedua adalah observation-participation-reflection yang dilakukan dalam bentuk focus group discussion kepada informan kunci dan informan general. Tahap selanjutnya yaitu wawancara mendalam (in depth interview) kepada 6 orang informan kunci dan 5 orang informan general. Dalam metode wawancara pada informan kunci dan informan general menggunakan wawancara semi terstruktur dan panduan wawancara yang berdurasi 45 - 60 menit pada setiap partisipan. Proses focus group 
discussion dan wawancara kemudian direkam dan ditranskripsikan. Dalam 2 metode transcultural nursing tersebut responden didorong untuk mengekspresikan pengalaman dan perasaan mereka terkait kehidupan mereka sebagai perempuan Bugis Makassar yang berstatus HIV/AIDS positif.

Penelitian ini dilakukan selama kurun waktu 3 bulan dimulai dari bulan JuliSeptember 2021. Dimulai dengan persiapan instrumen penelitian berupa kuesioner rosenberg self esteem scale dan kuesioner kualitas hidup serta pedoman wawancara semi terstruktur dan juga pedoman FGD. Hasil data yang didapatkan melalui pengumpulan data digunakan untuk menjawab pertanyaan peneliti terkait pengaruh budaya siri' na pacce terhadap self esteem perempuan dengan HIV/AIDS di kota Makassar dengan menggunakan pendekatan transcultural nursing serta faktor-faktor yang mempengaruhi self esteem perempuan dengan HIV/AIDS di kota Makassar.

\section{HASIL PENELITIAN}

Tabel. 1

Data Demografis Informan Kunci

\begin{tabular}{|c|c|c|}
\hline & $\mathrm{N}$ & $\%$ \\
\hline \multicolumn{3}{|l|}{ Jenis Kelamin } \\
\hline Perempuan & 6 & 100.0 \\
\hline \multicolumn{3}{|l|}{ Agama } \\
\hline Islam & 6 & 100.0 \\
\hline \multicolumn{3}{|l|}{ Suku } \\
\hline Bugis & 3 & 50.0 \\
\hline Bugis Makassar & 1 & 16.7 \\
\hline Makassar & 2 & 33.3 \\
\hline \multicolumn{3}{|l|}{ Pendidikan Terakhir } \\
\hline SMA & 5 & 83.3 \\
\hline D3 & 1 & 16.7 \\
\hline \multicolumn{3}{|l|}{ Status Perkawinan } \\
\hline Cerai Mati & 4 & 66.7 \\
\hline Cerai Hidup & 1 & 16.7 \\
\hline Menikah & 1 & 16.7 \\
\hline \multicolumn{3}{|l|}{ Status Tinggal } \\
\hline Extended Family & 3 & 50.0 \\
\hline Nuclear Family & 3 & 50.0 \\
\hline \multicolumn{3}{|l|}{ Pekerjaan } \\
\hline Bekerja & 3 & 50.0 \\
\hline Tidak Bekerja & 3 & 50.0 \\
\hline \multicolumn{3}{|l|}{ Besar Penghasilan } \\
\hline$<$ Rp.1.000.000 & 1 & 16.7 \\
\hline Rp.1.000.000-2.500.000 & 2 & 33.3 \\
\hline$>2.500 .000$ & 3 & 50.0 \\
\hline Total & 6 & 100.0 \\
\hline
\end{tabular}

Berdasarkan tabel 1 diperoleh total responden yang berjenis kelamin perempuan adalah 6 orang. Adapun berdasarkan suku, diperoleh total responden yang berasal dari suku Bugis adalah 3 orang, berasal dari suku Bugis Makassar adalah 1 orang, dan berasal dari suku Makassar adalah 2 orang. Adapun berdasarkan pendidikan terakhir, diperoleh total responden dengan pendidikan terakhir Sekolah Menengah Atas (SMA) adalah 5 orang dan D3 (Diploma 3) adalah 1 orang. Adapun berdasarkan status 
perkawinan, diperoleh total responden dengan status perkawinan cerai mati adalah 3 orang, cerai hidup adalah 1 orang, dan menikah adalah 1 orang.

Adapun berdasarkan status tinggal, diperoleh total responden dengan status extended family (ayah, ibu, anak, nenek/kakek/paman/bibi) adalah 3 orang dan nuclear family (ayah, ibu, anak) adalah 3 orang. Adapun berdasarkan pekerjaan, diperoleh total responden yang bekerja adalah 3 orang dan tidak bekerja adalah 3 orang. Adapun berdasarkan besar penghasilan, diperoleh total responden yang memiliki besar penghasilan <Rp.1.000.000 adalah 1 orang, total responden yang memiliki besar penghasilan Rp.1.000.000-Rp.2.500.000 adalah 2 orang, dan total responden yang memiliki besar penghasilan >Rp.2.500.000 adalah 3 orang.

Tabel. 2

Data Demografi Informan General

\begin{tabular}{cccc}
\hline Inisial & Usia (Tahun) & Jenis Kelamin & Hubungan dengan Informan Kunci \\
\hline IG1 & 23 & Perempuan & Saudara \\
IG2 & 60 & Perempuan & Ibu \\
IG3 & 64 & Perempuan & Ibu \\
IG4 & 39 & Perempuan & Saudara \\
IG5 & 38 & Laki-laki & Teman dekat \\
\hline
\end{tabular}

Berdasarkan tabel 2 informan general yang turut serta dalam penelitian ini akan tetap dijaga privasinya sehingga nama aslinya diganti dengan menggunakan kode IG1, IG2, IG3, IG4, IG5 yang berarti IG1 adalah informan general 1, IG2 informan general 2, IG3 informan general 3 dan seterusnya.

Tabel. 3

Data Self-Esteem

\begin{tabular}{lll}
\hline Kuesioner Self-Esteem & N & $\%$ \\
\hline Self-Esteem: Penerimaan Diri & & \\
Rendah & 1 & 16.7 \\
Sedang & 4 & 66.7 \\
Tinggi & 1 & 16.7 \\
\hline Self-Esteem: Penghormatan Diri & & \\
Rendah & 0 & 00.0 \\
Sedang & 4 & 66.7 \\
Tinggi & 2 & 33.3 \\
\hline Total & 6 & 100.0 \\
\hline
\end{tabular}

Berdasarkan tabel 3 adapun berdasarkan hasil kuesioner self esteem yang terdiri dari indikator penerimaan diri dan penghormatan diri, diperoleh total responden dengan tingkat penerimaan diri yang rendah adalah 1 orang, sedang adalah 4 orang, dan tinggi adalah 1 orang. Sedangkan untuk self esteem indikator penghormatan diri, diperoleh total responden dengan penghormatan diri yang rendah adalah tidak ada, yang sedang ada 4 orang, dan yang tinggi sebanyak 2 responden. Secara keseluruhan, total responden dalam penelitian ini adalah 6 orang dengan tingkat self esteem pada indikator penerimaan diri dan penghormatan diri yang cenderung sedang, sehingga masih perlu peningkatan self esteem agar mencapai tingkat yang tinggi.

Selain data dari kuesioner, peneliti juga melakukan wawancara secara mendalam (indeph interview) kepada 6 informan kunci dan 5 informan general yang memenuhi kriteria inklusi dengan durasi 45-60 menit. Peneliti mendapatkan data bahwasanya tingkat 
self esteem perempuan dengan HIV/AIDS di Kota Makassar dipengaruhi oleh adanya faktor budaya. Hal ini sejalan dengan pendekatan yang digunakan dalam penelitian ini yakni transcultural nursing. Pengkajian transcultural nursing dilakukan dengan menggunakan sunrise model yang terdiri dari 7 (tujuh) faktor untuk mengidentifikasi masalah kesehatan berdasarkan latar belakang budaya sehingga didapatkan faktor dominan yang mempengaruhi self esteem perempuan dengan HIV/AIDS di Kota Makassar.

Dari hasil wawancara didapatkan data semua responden mengatakan bahwa mereka mendapatkan virus HIV dari suami/pasangan mereka, dan baru mengetahui status HIV/AIDS suaminya setelah suaminya dalam kondisi kronis seperti yang diungkapkan oleh responden $\mathrm{A}$

"Awalnya saya kaget, saya tidak tahu kalau suami saya dulu pengguna narkoba. Waktu ditanya sama orang tuanya kalau dulu suami saya pemakai narkoba (jarum suntik), jadi yah saya bilang saya terinfeksi dari suami saya".

Responden juga mengungkapkan di awal mengetahui statusnya mereka tidak percaya dan bertanya-tanya dari mana mereka mendapatkan statusnya. Responden juga mengatakan kalau di awal mereka merasa denial/susah menerima, karena mereka berlaku baik seperti yang diungkapkan oleh responden $\mathrm{N}$

"Saya awalnya itu eek ok bisa? Pertanyaanku di awal lagi kok bisa? Dari mana toh?"

Selanjutnya peneliti pun melakukan wawancara untuk mengetahui faktor yang paling mempengaruhi tingkat self esteem ODHA, dan didapatkan hasil bahwasanya siri' na pacce adalah faktor yang sangat berpengaruh, dimana perempuan ODHA akhirnya merasakan siri' (malu) dengan keadaannya dan kemudian menutupi statusnya, seperti yang disampaikan responden I

"Pokoknya selama ada penyakitku lose contact-ka sama temanku, nda bergaulma. Sa kurung diriku, keluarga semuanya pada tahu tapi sayanyaji yang minder. Sayanya ji yang minder, kek merasa takutka bilang nanti orang beranggapan bagaimana to"

Selain ODHA itu sendiri, keluarga/kerabat dekat mereka juga merasa ripakasiri' (dipermalukan) apabila status HIV keluarga mereka diketahui oleh masyarakat. Siri' dalam makna ripakasiri' karena status ODHA yang dimiliki keluarganya seperti yang diungkapkan oleh responden $\mathrm{M}$

"Ndak beranika deh karena orang kampung semua, orang kampung, nda ditauki anunya, nda ditau juga bilang mengertika atau tidak, nanti nda maumi ke rumah, nda maumi namakan makananta"

Pernyataan yang sama juga disampaikan oleh salah satu informan general $\mathrm{P}$ yang mengatakan bahwa:

"Terus nda lama keknya itu suaminya meninggal, meninggal sekitar 1 bulan setelah ketemu sama dia, terus sempet main ke rumahnya itu di rumahnya itu agak gimana ya, dia agak distigma sama keluarganya suaminya. Jadi satu rumah itu dengan 2 dapur. L masak sendiri, mertuanya masak sendiri kaya dikucilkan gitu kan yaa dia akhirnya memilih untuk ngekos sendiri gitu"

Namun beberapa responden juga mengatakan bahwa mereka menjadi tegar dan mampu menerima statusnya karena menerima dukungan dari keluarga dan orang terdekatnya. Beberapa responden mengungkapkan bahwa mereka dapat beradaptasi dengan 
baik karena keluarga, terutama Ibu yang selalu mendampingi dan memberikan dukungan, serta menerima status mereka sebagai ODHA.

\section{PEMBAHASAN}

Hasil penelitian yang telah dilakukan menunjukkan bahwasanya seluruh ODHA mendapatkan virus HIV dari pasangan mereka dan terdeteksi pada saat pasangan mereka sudah dalam keadaan kronis dan bahkan sudah terjadi komplikasi. Sehingga, kemungkinan untuk meningkatkan kualitas hidupnya dan memperpanjang usia relatif rendah (Tumina \& Yona, 2019). Oleh karena itu deteksi dini HIV sangatlah penting selain mencegah terjadinya penurunan kualitas hidup ODHA dan komplikasi-komplikasi yang bisa terjadi.

Mengetahui bahwasanya tubuh telah terinfeksi HIV tentunya menimbulkan stress psikologis bagi kebanyakan orang. Sebagian besar responden dalam penelitian ini di awal merasa tidak terima dan susah untuk menerima keadaan mereka. Beberapa dari mereka juga bahkan menarik diri dari lingkungannya. Berbagai masalah psikologis memang sangat rentan terjadi pada ODHA ditambah lagi jika mereka merasakan diskrimisasi oleh lingkungan sekitarnya (Prathama et al., 2020). Hal ini tentunya dipengaruhi oleh berbagai faktor. Dalam penelitian ini sendiri diidentifikasi bahwasanya nilai budaya dalam hal ini siri' na pacce sangat berpengaruh terhadap self esteem perempuan ODHA. Nilai budaya siri' na pacce yang mereka anut menimbulkan rasa takut, ragu, cemas untuk terbuka kepada lingkungan masyarakat terkait status mereka sehingga, mereka cenderung tertutup dan hanya berani mengatakan status ODHA mereka kepada keluarga, teman atau kerabat terdekat.

Budaya siri' ini berkembang oleh karena pengaruh internal dan eksternal. Kedua faktor ini menyumbang pengaruh yang besar. Pertama, faktor internal yaitu berasal dari diri ODHA itu sendiri. Tanpa sadar ODHA menarik dirinya dari lingkungan sosial, mereka membuat batasan dengan lingkungan pertemanan bahkan mengurung dirinya sendiri oleh karena perasaan siri' atau malu yang mereka rasakan. Kedua, faktor eksternal adalah oleh karena pengaruh keluarga/kerabat ODHA itu sendiri. Timbulnya perasaan ripakasiri' (dipermalukan) oleh keluarga mereka yang merupakan ODHA. Perasaan ripakasiri' ini timbul oleh karena stigma buruk yang sangat melekat pada ODHA. Oleh karena itu, keluarga/kerabat akhirnya akan mencoba untuk membela kehormatan dan harga diri mereka untuk menegakkan siri' di masyarakat. Membuat orang Bugis malu di depan umum, akan membangkitkan rasa siri' ripakasiri' dalam dirinya, dan ini merupakan suatu penghinaan yang dapat menimbulkan perasaan yang membara dalam diri orang Bugis (Widiansyah \& Hamsah, 2018).

Faktor sosial dapat menjadi sistem pendukung bagi perempuan ODHA sekaligus sumber timbulnya stigma dan diskriminasi terhadap ODHA. Penilaian negatif dari keluarga atau kerabat dekat menyebabkan ODHA memilih untuk menyembunyikan statusnya. Walaupun begitu, dukungan keluarga juga menjadi salah satu alasan perempuan ODHA untuk tetap tegar, dan semangat menjalani hidupnya. Dukungan dari keluarga juga memudahkan mereka dalam beradaptasi dengan keadaannya, membuat mereka akhirnya dapat berdamai dan menerima status mereka sebagai ODHA.

Faktor pendidikan, lebih tepatnya tingkat pengetahuan masyarakat tentang HIV/AIDS ternyata dapat mempengaruhi self esteem ODHA. Pengetahuan tentang HIV/AIDS sangat mempengaruhi bagaimana individu tersebut akan bersikap terhadap penderita HIV/AIDS (Soares et al., 2020). Kemudian Andersson et al., (2020) juga mengatakan bahwa salah satu penyebab terjadinya stigma adalah misinformasi mengenai bagaimana HIV ditransmisikan. Hal ini sejalan dengan penelitian yang dilakukan oleh Haeriyanto et al., (2019) dimana 
terdapat hubungan signifikan antara pengetahuan dengan stigma. Terdapat perbedaan secara bermakna rata-rata skor stigma kelompok intervensi antara sebelum dan sesudah pemberian pendidikan kesehatan tentang HIV dan AIDS.

\section{SIMPULAN}

Budaya siri'na pacce memiliki pengaruh terhadap perempuan dengan HIV/AIDS di Kota Makassar. Faktor lain yang mempengaruhi tingkat self esteem berdasarkan pendekatan transcultural nursing adalah faktor nilai budaya dan gaya hidup serta faktor tingkat pengetahuan. Penting dilakukan adanya penelitian lebih lanjut terkait bagaimana budaya setempat dapat mempengaruhi kondisi sehat sakit masyarakat. Pendekatan transcultural nursing ini memungkinkan untuk direplikasi sebagai salah satu intervensi berbasis budaya dalam memahami penyakit menular lainnya, seperti TB Paru bahkan COVID-19 yang dapat diterapkan di seluruh wilayah Indonesia.

\section{SARAN}

Agar peneliti selanjutnya lebih mengeksplor faktor-faktor budaya yang dapat mempengaruhi self esteem perempuan dengan HIV/AIDS yang sesuai dengan teori transcultural nursing sehingga dapat memberikan hasil yang lebih beragam sehingga dapat dijadikan salah satu intervensi berbasis budaya yang dapat direplika ke dalam berbagai kasus penyakit menular seperti TB Paru hingga COVID-19.

\section{DAFTAR PUSTAKA}

Andersson, G. Z., Reinius, M., Eriksson, L. E., Svedhem, V., Esfahani, F. M., Deuba, K., Rao, D., Lyatuu, G. W., Giovenco, D., \& Ekström, A. M. (2020). Stigma Reduction Interventions in People Living with HIV to Improve Health-Related Quality of Life. The Lancet HIV, 7(2), e129-e140. https://doi.org/10.1016/S2352-3018(19)30343-1

Andri, J., Ramon, A., Padila, P., Sartika, A., \& Putriana, E. (2020). Pengalaman Pasien ODHA dalam Adaptasi Fisiologis. Journal of Telenursing (JOTING), 2(2), 127-141. https://doi.org/https://doi.org/10.31539/joting.v2i2.1397

Fuady, M. I. N. (2019). Siri' Na Pacce Culture in Judge's Decision (Study in Gowa, South Sulawesi Province). Fiat Justisia:Jurnal Ilmu Hukum, 13(3), 241. https://doi.org/10.25041/fiatjustisia.v13no3.1684

Haeriyanto, S., Ekarini, N. L. P., \& Lusiani, D. (2019). Stigma Remaja terhadap ODHA Studi terhadap pelajar SMA di wilayah Jakarta Timur. JKEP, 4(1), 12-23. DOI: 10.32668/jkep.v4i1.277

Hijriani, H., \& Herman, H. (2019). The Value of Siri'na Pacce as an Alternative to Settle Persecution. Padjadjaran Jurnal Ilmu Hukum (Journal of Law), 5(3), 558-580. https://doi.org/10.22304/pjih.v5n3.a9

Im, E. O., \& Lee, Y. (2018). Transcultural Nursing: Current Trends in Theoretical Works. Asian Nursing Research, 12(3), 157-165. https://doi.org/10.1016/j.anr.2018.08.006

Khairunisa, S. Q., Megasari, N. L. A., Ueda, S., Budiman, W., Kotaki, T., Nasronudin, \& Kameoka, M. (2020). 2018-2019 Update on the Molecular Epidemiology of HIV-1 in Indonesia. AIDS Research and Human Retroviruses, 36(11), 957-963. https://doi.org/10.1089/aid.2020.0151

Maharani, I. (2018). Cap Orang dengan HIV dan AIDS (ODHA) Studi Sosiologi Kualitatif tentang Stigma. Universitas Airlangga 
McFarland, M. R., \& Wehbe-Alamah, H. B. (2019). Leininger's Theory of Culture Care Diversity and Universality: An Overview With a Historical Retrospective and a View Toward the Future. Journal of Transcultural Nursing, 30(6), 540-557. https://doi.org/10.1177/1043659619867134

Moreno-de-Lara, L., Parthasarathy, R. S., \& Rodriguez-Garcia, M. (2021). Mucosal Immunity And Hiv Acquisition In Women. Current Opinion in Physiology, 19, 3238. https://doi.org/10.1016/j.cophys.2020.07.021

Pardede, J. A., Hafizuddin, H., \& Sirait, A. (2021). Strategi Koping dengan Harga Diri ODHA di Yayasan Medan Plus. Jurnal Ilmu Keperawatan Jiwa, 4(2), 255-262. https://journal.ppnijateng.org/index.php/jikj

Prathama, L. N., Putri, W. C. W. S., \& Sari, K. A. (2020). Gambaran Dampak Psikologis, Sosial dan Ekonomi pada ODHA di Yayasan Spirit Paramacitta Denpasar. Intisari Sains Medis, 11(1), 81. https://doi.org/10.15562/ism.v11i1.208

Safitri, A., \& Suharno, S. (2020). Budaya Siri' Na Pacce dan Sipakatau dalam Interaksi Sosial Masyarakat Sulawesi Selatan. Jurnal Antropologi: Isu-Isu Sosial Budaya, 22(1), 102. https://doi.org/10.25077/jantro.v22.n1.p102-111.2020

Shimizu, H., Takahashi, C., Koike, M., Fukui, K., \& Nakashima, K. (2021). How do Changes in One's Self-Esteem Affect the Self-Esteem of Others? Japanese Psychological Research. https://doi.org/10.1111/jpr.12350

Soares, J. L., Silva, I. G. B., Moreira, M. R. L., Martins, Á. K. L., Rebouças, V., De, C. F., \& Cavalcante, E. G. R. (2020). Transcultural Theory in Nursing Care of Women with Infections. Revista Brasileira De Enfermagem, 73, e20190586. https://doi.org/10.1590/0034-7167-2019-0586

Timisela, J. (2018). Dukungan Informasional Berhubungan dengan Stigma HIV pada $\begin{array}{llll}\text { Perempuan } & \text { Positif HIV. } & \text { 15-21. }\end{array}$ https://www.jurnalpoltekkesmaluku.com/index.php/JKT/article/download/7/5

Tumina, M. S., \& Yona, S. (2019). Perilaku Seksual Berisiko sebagai Salah Satu Faktor yang Memengaruhi Peningkatan Kasus HIV/AIDS pada Perempuan. Jurnal Keperawtan, 12(4), 513-522. http://journal.stikeskendal.ac.id/index.php/Keperawatan/article/download/833/524

WHO. (2020). News Room HIV/AIDS. World Health Organization. https://www.who.int/news-room/fact-sheets/detail/hiv-aids

Widiansyah, S., \& Hamsah, H. (2018). Dampak Perubahan Global terhadap Nilai-Nilai Budaya Lokal dan Nasional (Kasus pada Masyarakat Bugis-Makasar). Jurnal Hermeneutika, 4(1), 38-48. http://dx.doi.org/10.30870/hermeneutika.v4i1.4822

Yani, F., Harahap, F. S. D., \& Hadi, A. J. (2020). Stigma Masyarakat terhadap Orang dengan HIV/AIDS (ODHA) di Kabupaten Aceh Utara. The Indonesian Journal of Health Promotion, $3(1)$. http://jurnal.unismuhpalu.ac.id/index.php/MPPKI/article/view/1028

Zainal, X., \& Wahyuni, S. (2018). Siri' na Passe dalam Masyarakat Bugis di Kota Tanjungpinang. Jurnal Masyarakat Maritim, 2(1). https://www.neliti.com/id/publications/327898/siri-na-pesse-dalam-masyarakatbugis-di-kota-tanjungpinang 